\title{
ÖNGYILKOS MERÉNYLETEK EGYIPTOMBAN A 2004 ÉS 2020 KÖZÖTTI IDŐSZAKBAN - AZ ÖNGYILKOS MERÉNYLETEK ELKÖVETÉSI MÓDJAINAK VIZSGÁLATA SZERVEZETTSÉG ALAPJÁN, A VALLÁS SZEREPÉNEK FIGYELEMBEVÉTELÉVEL
}

Suicide Bombings in Egypt Between 2004 and 2020 Examination of Methods of Conducting Suicide Attacks on the Basis of Organization, Taking Into Account the Role of Religion

\section{Majorosi Ádám ${ }^{1}$}

\begin{abstract}
Absztrakt: Jelen tanulmányban az egyiptomi öngyilkos merényleteket tárgyalom, erről a témáról pedig eddig ilyen átfogó munka magyar nyelven nem született. A tanulmány a merényletek okaival, fejlődésével is foglalkozik. A tanulmány első része a Mubárak-korszak utolsó éveinek támadásait mutatja be. Közös bennük, hogy föleg nem szervezett támadásokról volt szó, amelyet néhány egyén követett el, és amelyek nehezen nevezhetőek öngyilkos merényletnek. A következő fejezet főleg az arab tavasz utáni időszakot elemzi a Muszlim Testvériség megbuktatásáig. Ekkor összesen egy öngyilkos merényletet hajtottak végre, amelynek okai vélhetően a kormányzó erő muszlim volta, és a terrorcsoportok szervezetlensége, a támadások ad-hoc jellege lehettek. Végezetül a Szíszikorszakkal foglalkozom, ekkor jelentős számban megnövekedtek az öngyilkos merényletek. Vélhetően a szélsőséges szervezetek a Testvériség megbuktatása után „hitetlennek” látták a hadsereget, amely ellen igazolhatóvá váltak az öngyilkos merényletek. Ráadásul az elkövetőkre hatással lehetett az Iszlám Állam tevékenysége is, és ekkorra a terrorcsoportok szervezeti felépítése is megszilárdult. A tanulmányt a „Következtetésekkel” zárom.
\end{abstract}

\footnotetext{
${ }^{1}$ Majorosi Ádám, Nemzeti Közszolgálati Egyetem, Hadtudományi Doktori Iskola. ORCID: https://orcid.org/0000-0003-2939-3103

A szerző további munkásságát lásd a Magyar Tudományos Művek Tára oldalán: https: $/ / \mathrm{m} 2 . \mathrm{mtmt}$.hu/gui2 $/$ ?type $=$ authors\&mode $=$ browse\&sel $=10078066$
} 
Kulcsszavak: Egyiptom, öngyillkos merényletek, Mubárak, Muszlim Testvériség, Iszlám Állam, terrorizmus

\begin{abstract}
In this study, I will examine the suicide bombings in Egypt, which area was not studied yet in such an essay. This work contains information about the causes and developments of these attacks. In the first part, I would like to write about the attacks of the last years during the Mubarak administration. These attacks were unorganized, made by different actors, and happened unintentionally. The next chapter will examine the years of the Arab Spring until the coup against the Muslim Brotherhood. In these years, there was only one suicide bombing. In my view, the radical groups did not make any suicide attacks because the government openly declared its Muslim identity, and the terrorist groups were also unorganized. In the last chapter, I would like to examine the Sisi era from 2013 to nowadays. The number of suicide bombings have grown significantly. The main cause of increase was the coup against the Brotherhood, which made the military ,infidel” in the eyes of the radical groups, so the suicide bombings were religiously legitimized. We could find other reasons, such as the influence of the Islamic State or the organizational and operational development of the terrorist groups in Egypt. I would like to finish this study with the „Conclusion”.
\end{abstract}

Keywords: Egypt, suicide bombings, Mubarak, Muslim Brotherhood, Islamic State, terrorism

\title{
BEVEZETÉS
}

Egyiptomban a 2011-es arab tavasz óta került erőteljesebb fókuszba a terrorellenes küzdelem. Ennek keretében az egyiptomi hadsereg fóleg a Sínai-félszigeten, a beduin törzsek között jelen levố terrorszervezetek ellen folytat műveleteket. Ezek a csoportok az aszimmetrikus hadviselés módszereit alkalmazva igyekeznek sikereket elérni a biztonsági erők ellen, eszközeik között megtalálhatók a pokolgépes merényletek, a katonákkal folytatott gyors tűzpárbajok, és az öngyilkos merényletek is. Az öngyilkos merényletek alkalmazása sok kérdést vet fel, és nehezen megragadható. Ennek alátámasztására több okot lehet felsorolni. Gyakran például olyan merényletet sorolnak ezek közé az egyiptomi hatóságok, amelyek 
Öngyilkos merényletek Egyiptomban a 2004 és 2020 közötti időszakban - Az öngyilkos merényletek elkövetési módjainak vizsgálata szervezettség alapján, a vallás szerepének

figyelembevételével

elkövetésük módját tekintve nem ebbe a kategóriába tartoznának. Például a 2004-es Taba-i merénylet utáni vizsgálatok kimutatták, hogy a kocsiba rejtett pokolgépre egy mosógép időzítőjét szerelték. Azonban a beszerelés nem volt megfelelő minőségú, és a bomba vélhetően hamarabb robbant, mint kellett volna. ${ }^{2} \mathrm{Ez}$ azt bizonyíthatja, hogy az elkövető nem volt öngyilkos merénylő. Másrészt az sem mindig bizonyítható, hogy melyik szervezet követte el a merényletet. Előfordul, hogy annak a terrorcsoportnak nem feltétlenül volt köze hozzá, amelyik például azonnal felvállalta annak elkövetését.

Ebben a tanulmányban az öngyilkos merényletek összetett kérdéskörét járom körbe Egyiptom példáján keresztül. ${ }^{3} \mathrm{Az}$ öngyilkos merényletek kapcsán előfordul, hogy redundáns információk kerülnek a kutató birtokába, és ezekből kell a tényeket szemügyre vennie. A jelenlegi terrorellenes küzdelemben a merényleteknek identifikációs szerepe is lehet, tekintve, hogy nagy részben az öngyilkos merényleteket az Iszlám Állam Sínai-félszigeti csoportja hajtotta végre. Ennek oka hipotézisem szerint az, hogy egyrészt a terrorszervezet számára jelentős humánerőforrás állt rendelkezésre, amely lehetôvé tette ezen eszköz alkalmazását. Valamint, amikor 2013-ban hűséget esküdtek az Iszlám Államnak ${ }^{4}$ akkor átvették annak „hadikultúráját”, hasonló műveleteket alkalmaztak, és vélhetően a korábbi szervezetbe az Iszlám Állam tagjai is csatlakozhattak, akik ezeket tervezhették. A tanulmány tárgyalása három különálló részre bontható. Az első egységben történelmi áttekintést szeretnék adni. Ebben a fejezetben a Muszlim Testvériség megalakulásáról, harcáról az egyiptomi hadsereggel szemben, annak belső szakadásáról, amely végül több különálló csoport megalakulását tette lehetôvé. Ezek később a hadsereggel szembeni harcokban is részt vettek (gyanítható, hogy a Harakat Sāwa'd Miṣr, HASM terrorszervezetben is voltak Muszlim Testvériség tagok). ${ }^{5}$

A fejezetben vizsgálandó folyamatok több szállal kapcsolódnak az öngyilkos merényletekhez. A Muszlim Testvériség szakadása (1964.) után a szélsőséges szárny Szajjid Kutb ideológiáját tette magáévá, amely szerint az olyan muszlim kormányzatok, amelyek saját lakosságuk ellen alkalmaznak erőszakot, nem tekinthetőek muszlimnak, így ellenük a dzsihád

\footnotetext{
2 Human Rights Watch Jelentés, Mass Arrest and TORTure in SinAi, 2005.

3 Az öngyilkos merényletek tipológiájáról, valamint történelmi áttekintéséről ad átfogó képet az alábbi tanulmány: POLAND, 2003.

${ }^{4}$ ISLAMIC STATE: EGYPTIAN MILITANTS PLEDGE LOYALTY, 2013.

${ }^{5}$ KIRKPATRICK, 2019.
} 
megengedett. Ezt az ideológiát a Sínai Vilájet nevú szervezet is alkalmazza, amikor öngyilkos merényleteket hajtott végre 2013 után az egyiptomi hadsereg ellen, mivel azok a Muszlim Testvériség megbuktatása során jelentős számban muszlim egyiptomiakat öltek meg. Ez a hatalomváltás növelte a radikalizmus térnyerését az országban, amely megkönnyítette a terrorcsoportok térnyerését, és új tagok toborzását is. Ezek a szervezetek kezdetben a kormányt támadták, majd mivel nem tudtak ellene sikereket elérni, a turistákat vették célba. A 2004-es öngyillkos merényletek is főleg a turistákat, elsősorban az izraelieket értek, akikkel szemben megengedett az öngyilkos merénylet, amelyet elsősorban más vallású célpontok ellen alkalmazhatnak.

A soron következő fejezet az arab tavasz folyamatai megindulásának körülményeivel fog foglalkozni, és egészen a Murszi-korszakig fogja áttekinteni az eseményeket. Fontosnak tartom a Sínai-félsziget északi részén kitört felkelés okainak ismertetését. Ezt, bár korábban más tanulmányaimban is megtettem ${ }^{6}$, de nem hagyhatom ki, mivel fontos, hogy megértsük például azt, hogy hogyan tudott az Iszlám Állam megtelepedni a félszigeten. A fejezet egyik legfőbb megállapítása az, hogy öngyilkos merényletet csak egyet hajtottak végre a vizsgált időszakban. Véleményem szerint ebben annak volt jelentős szerepe, hogy muszlim kormány került hatalomra. Úgy vélem, hogy az öngyilkos merényletek gyakran kapcsolhatók vallási indokokhoz, így nem alkalmazták azokat a deklaráltan muszlim (iszlamista) vezetés alatt szolgáló katonák vagy kormányzati tisztviselők ellen.

A 2013 augusztusában lezajlott hatalomváltás azonban ebben a kérdésben is változást hozott. Megnövekedett az öngyilkos merényletek száma, és a célpontok is. Míg 2011 előtt főleg turisták ellen követtek el merényleteket, addig 2011 közepétől kezdve főleg katonák, rendőrök, kormányzati tisztviselők kerültek a célpontok közé. A merényletek száma 2013-tól kezdve növekedett meg. Az áldozatok jelentős részben az egyiptomi muszlim lakosság közül kerültek ki, mivel a terroristák nem tartották igazhitűnek az állami tisztviselőket, katonákat. Mivel 2013-ban iszlamista kormányzatot döntöttek meg, és a muszlimokkal szemben erőszakot alkalmaztak, ezért nem tartották őket igazhitűeknek. Az öngyilkos merényletek elterjedése az országban nagyrészt az Iszlám Állam egyiptomi megjelenésével is kapcsolatba hozható.

${ }^{6}$ Majorosi, 2020, 45.-68.o. és MAjOrosi, 2019., 81.-99.o. 
Öngyilkos merényletek Egyiptomban a 2004 és 2020 közötti időszakban - Az öngyilkos merényletek elkövetési módjainak vizsgálata szervezettség alapján, a vallás szerepének

figyelembevételével

Két hipotézis vizsgáltam ebben a tanulmányban. Az egyik ilyen az volt, hogy Egyiptomban szervezetten hajtottak végre öngyilkos merényleteket, amelyek mögött mindig terrorcsoportok álltak. Ennek vizsgálatára igyekeztem példákat összehasonlítani, és igazolni az első hipotézist, amely csak félig volt igaz, ugyanis szervezett merényleteket csak a Sínai Vilajet alkalmazott, a merényletek jelentős rész ad-hoc-nak bizonyult, és inkább a véletlennek köszönhetően váltak azzá, semmint előzetes tervezés eredményeként. A másik hipotézis szerint ezeket a merényleteket vallási motivációból követték el. Ez jelentôs részben igaz volt, azonban a Sínai Vilajet, például gyakran hadászati eszközként alkalmazta az öngyilkos merényleteket. De az ad-hoc merényletek sem tủntek el, a városi térségben még követtek el hasonlókat.

\section{A MUBÁRAK KOR, ÉS AZ ÖNGYILKOS MERÉNYLETEK}

A Szadat elleni merénylet után Hoszni Mubárak lett az elnök, aki az 1973-as háború során a légierőt vezette. ${ }^{7}$ Mubárakra jelentős befolyást gyakorolt Szadat likvidálása, mivel azt közvetlen közelről nézte végig. Ezért uralma során kemény kézzel igyekezett a terrorcsoportokkal szemben fellépni. Ehhez a legfőbb eszköze a szükségállapot bevezetése volt. Ezt évente meghosszabbították, amely lehetőséget biztosított az elnök számára, hogy bármilyen eszközt alkalmazhasson a terrorcsoportok ellen. ${ }^{8}$ Mubárak, elődjéhez hasonlóan, igyekezett az al-Azhar tevékenységét is igénybe venni, és a saját céljaira felhasználni. Mivel a szélsőségesek a vallási érvrendszert használták fel a rendszer ellen, ezért Mubárak is ezt fordította ellenük. ${ }^{9}$ Másrészt pedig igyekezett megnyerni magának az embereket, például a sariát mint a törvények forrását beleírták az alkotmányba, vallási műsorokat is engedélyezett a televízióban, hogy ezzel is saját támogatását növelje. Fontos eszköznek bizonyult az alkotmány új, 179-es cikkének elfogadása, ${ }^{10}$ amely a terrorcsoportok merényleteinek hatására különleges jogköröket biztosított az elnök számára. Így például a terrorgyanús elemeket már nem a polgári bíróság, hanem a katonai bíróságok itélhették el. Ez pedig az elnöknek

\footnotetext{
${ }^{7}$ Hoszni Mubárak 1981. október és 2011. február között töltötte be az elnöki tisztséget.

${ }^{8}$ CSICSMANN, 2010. 200.o.

9 ZEGHAL, 1999. 16.o.

${ }^{10}$ CONSTITUTIONAL History OF EGYPT
} 
szabad kezet adott nemcsak a terrorszervezetek, hanem az ellenzéki szereplők elleni fellépésre is. ${ }^{11}$

Mubárak nemcsak a terrorcsoportokkal, hanem a Muszlim Testvériség szervezetével szemben is vezetett be korlátozó intézkedéseket. Ellenük főképpen politikai módszereket alkalmazott, mivel a Muszlim Testvériség már a választások útján tervezte meg a hatalom megragadását. ${ }^{12}$ Így Mubárak főleg a választási törvények módosításával, a Testvériség médiaszerepléseinek csökkentésével, vagy például jelentős letartóztatási hullámmal próbálta aláásni a választási szereplésüket. ${ }^{13}$

Egyiptomban Mubárak elnökségéig nem volt öngyilkos merénylet. Az első ilyen támadásra 2004. október 7-én került sor a Sínai-félsziget déli részén. Ekkor egyidejủleg három merényletet hajtottak végre. Egyet Tabánál, a másik kettőt pedig a körülötte lévő kempingekben. A legnagyobb pusztítást a tabai Hilton Hotel szenvedte el, amelynek szalonjába behajtott egy robbanóanyaggal megpakolt tehergépkocsi. ${ }^{14}$ A robbanás következtében a hotel homlokzata beomlott, és a lobby helyiséget, valamint a földszinti szobákat is súlyos károk érték. Ez tekinthetô a fó támadásnak. Ezen a napon még két másik támadást hajtottak végre a turisták körében kedvelt sátorozó helyek ellen. Azonban a második robbantás nem követelt áldozatokat. Az egyiptomi hatóságok azonnal jelentős letartóztatásokba fogtak, hogy felszámolják a végrehajtó terrorcsoportot, valamint elfogják a merényletekben a lehetséges közreműködőket. Azonban a letartóztatások jelentős része a környékbeli beduin településeket érintette.

Többszáz főt tartóztattak le mindenféle vád nélkül, aztán elengedték őket. Később azonban az egyiptomi hatóságok bejelentették, hogy öt személyt tartóztattak le, akik segíthettek a merénylet végrehajtásában. Köztük volt autószerelőműhelyt üzemeltető személy, elektronikai szaküzletekben dolgozó (aki az alkatrészeket biztosította), de információ forrás is. Azt azonban a hatóságok nem árulták el, hogy milyen bizonyítékok alapján emeltek vádat ellenük. Közben a tabai merénylőre is fény derült, akit Ilijád Szafahnak hívtak. Az adatok alapján egy korábbi bűnözőről van szó, aki a börtönben radikalizálódott, és vélhetően ez volt a fő motivációja a támadás elkövetésére. Bár a hivatalos közlemény szerint öngyilkos merénylet történt, azonban egyiptomi források szerint az első támadás vélhetően nem

\footnotetext{
${ }^{11}$ KIENLE, 1998. 199.o.

12 GAZDIK, 2017. 118-119.o.

13 KIENLE, 1998. 224.o.

14 VAUSE, 2004.
} 
Öngyilkos merényletek Egyiptomban a 2004 és 2020 közötti időszakban - Az öngyilkos merényletek elkövetési módjainak vizsgálata szervezettség alapján, a vallás szerepének figyelembevételével

volt annak tekinthető. Mindezt azzal magyarázzák, hogy a bombába egy mosógép időzítőjét szerelték, amely az ütközéskor korábban robbantotta a bombát. Így a merénylő képtelen volt arra, hogy elmeneküljön. ${ }^{15}$ A merénylet célpontjául azért választották Tabát és környékét, mert kedvelt turistaparadicsomnak számított. Főleg izraeli állampolgárok keresték, de több külföldi turista is szívesen utazott ide. Azonban az áldozatok többsége az egyiptomi dolgozók közül kerültek ki. Utánuk következtek az izraeliek 10 fővel, valamint két olasz és egy orosz állampolgár is meghalt a támadások során. ${ }^{16}$

A merényleteket a hivatalos álláspont szerint az al-Káidához köthető, Abdullah Azzám Brigádok követhették el. A csoportról nem sokan lehetett tudni, ráadásul a csoport valójában 2009-ben alakult Libanonban. Így valószínú, hogy a támadást egy helyi al-Kaida sejt követhette el. ${ }^{17}$ Azonban a nyomozás során nem sikerült kapcsolatot találni a Brigádok és a merénylők között. A merénylők ráadásul rokonok voltak, a második támadást a tabai végrehajtó testvére követte el. A merénylők el-Arís városából származtak, palesztinok voltak, és a nyomozók szerint a merényélet fő oka vélhetően egyéni bosszú lehetett. ${ }^{18}$

A következő merénylet alig egy év múlva következett be. 2005. április 7-én robbant bomba a kairói Khán al- Khalíli bazárban. A támadásra öt órakor került sor, amikor turistákkal volt telezsúfolva a bazár. A merényletben hárman vesztették életüket, többen megsérültek, mivel a bombába szögeket tettek, hogy növeljék a pusztítást. A támadást öngyilkos merényletnek gondolták, mivel a robbanástól nem messze találtak egy ismeretlen holttestet. Azonban az öngyilkos merénylet itt sem bizonyítható. ${ }^{19}$

A bomba pontban ötkor robbant, ami azt jelenti, hogy tervezett robbantással van dolgunk. Nem lehetett olyan, a támadásról készült visszaemlékezést olvasni, ahol merénylő is szerepelt volna. Másrészt a támadást perce pontosan, véleményem szerint időzitővel hajtották végre, ami megint csak az öngyilkos merényletet cáfolja. ${ }^{20}$ A későbbiek során is alkalmaztak hasonló merényletet, ahol házilag készített bombát használtak,

\footnotetext{
15 Human RightS WATCH REPORT, 2005.)

${ }^{16}$ FOREIGN MINISTRY OF ISRAEL REPORT, 2004.

17 ZUHUR, 2005.

18 HUMAN RightS WATCH REPORT, 2005.

19 MACFARQUHAR, 2005.

${ }^{20}$ WALLIS, 2005.
} 
és főleg turistákat vettek célba. Itt főleg a Gízai piramis melletti 2019-es merényletre gondolok, ami hasonló jellegzetességeket hordoz.

Ehhez a támadáshoz kapcsolódik egy másik, amelyet szintén Kairóban követtek el kevesebb, mint egy hónappal később, április 30-án. A merényletre egy üldözés következtében került sor. A rendőrség ugyanis Iháb Juszri Jaszín nyomában volt, akit közremúködőnek tartottak az április 7-ei merényletben. A férfi üldözés közben leugrott egy hídról és élesítette a nála lévő bombát, amit vélhetően a hivatalos közlemények ellenére nem magán robbantott fel, hanem ledobta a hídról. Eközben egy másik támadás is történt Kairó Régi városnegyedében. Két nő nyitott tüzet egy turistabuszra. ${ }^{21} \mathrm{~A}$ merényletben hárman sérültek meg, a két nő a merénylet végeztével agyonlőtte egymást. Nem lehet tudni pontosan mi volt a fó motivációja a támadásnak. Talán a turisták ellen követték el bosszúból, mivel a három elkövető rokona volt annak a férfinak, akit őrizetben tartottak az április 7-ei támadásban játszott szerepért. Vélhetően a férfi a bombával egy robbantásos merényletet tervezett végrehajtani, azonban rajtakapták. İgy menekülés közben lehajította a bombát, és utána ugorhatott. Azt sem lehet meghatározni, hogy a két nő jelre támadott volna, ami a robbanás hangja lehetett, vagy órára pontosan kezdték meg azt. Mindenesetre nem lehet összehangolt merényletről beszélni, így inkább a bosszúelmélet látszik megalapozottnak.

2005. július 23-án pedig ismét a Sínai-félszigeten követtek el három öngyilkos merényletet. Az elsőre Sarm el-Seikben került sor, ahol az öngyilkos merénylő egy autóba rejtett pokolgéppel robbantotta fel magát. A második támadásban az elkövető a Ghazala hotelbe hajtott be egy furgonnal, és a lobbyban robbantotta fel magát. Végül az utolsó támadás már nem öngyilkos merénylet volt, mivel egy parkolóhelyiségben egy táskába rejtett pokolgépet robbantottak fel. A támadásban 92-en haltak meg, a sebesültek száma pedig elérte a 117 foot. $^{22}$ A robbantásokban az előző támadáshoz képest hasonlóságok és jelentős különbségek is felfedezhetőek. Egyrészt mind a három támadásra a városban került sor, a külső kerületeket egyáltalán nem érintették. Másrészt már nemcsak a hotelt, de bazárt is ért támadás. Ezzel akarták maximalizálni a pusztítást.

Vélhetően az utolsó robbantást akkor akarták kivitelezni, amikor a menekülők igyekeztek elhagyni a várost az autóikkal, így növelve az

\footnotetext{
21 ThreE DEAD AFTER CAIRO ATTACKS, 2005.

22 MYRE. 2005.
} 
Öngyilkos merényletek Egyiptomban a 2004 és 2020 közötti időszakban - Az öngyilkos merényletek elkövetési módjainak vizsgálata szervezettség alapján, a vallás szerepének

figyelembevételével

áldozatok számát. Azonban az időzítő megint korábban robbantotta a bombát. A merényletek sorrendje is változott. A hotelben történt robbantás csak a második volt, az elsőt a bazárban követték el. Vélhetően azért változtattak rajta, mert nem akarták a hotel elleni támadással elriasztani a vásárlókat. Ezért először a bazárnál kezdtek.

$\mathrm{Az}$ is érdekes, hogy ez az első olyan támadás, amelyet már terrorszervezetek vállaltak fel. A merénylet után nem sokkal az Abdullah Azzám Brigádok vállalták a felelősséget, és az egy évvel ezelőtti támadást is elismerték. Valószínű azonban, hogy azt nem ők követték el, viszont az eseményeket lekövették. ${ }^{23}$ Hiszen, ha megnézzük, a támadás rendkívül hasonló volt az előző évihez, viszont a korábbi merényletet átalakították, hogy jobban megfeleljen a terrorszervezet számára. Másrészt a robbantásokat nagy pontossággal hajtották végre, ami jelentős szervezettséget takar. A támadás, csakúgy, mint a korábbi, a turistákat, különösképpen az izraeli állampolgárokat célozta. Ez jelentős csapást jelentett az egyiptomi turizmusra nézve, hiszen a város az országba érkező turisták kedvelt üdülőhelyének számít.

Az öngyilkos merényletek közül még egy támadást emelnék ki, amelyet a hivatalos nyilatkozatok rendre mint öngyilkos merényletet aposztrofálnak, de ez nem igazán bizonyítható. 2011. január 1-jén robbant bomba Alexandria keleti részében, az újévi kopt keresztény mise közben. 21-en vesztették életüket, 96-an sebesültek meg, köztük 8 muszlim is. A támadásért nem vállalta senki a felelősséget, az egyiptomi hatóságok viszont öngyilkos merényletet állapítottak meg. ${ }^{24}$ A nyomozások után a hatóságok azt nyilatkozták, hogy egy öngyilkos mellényt viselő férfi robbantotta fel magát a templom mellett. Azonban a szemtanúk beszámolói alapján az autóba rejtett pokolgép a valószínű. Érdekes továbbá, hogy a beszámolók szerint a támadók az autóban ültek, viszont abban a visszaemlékezések eltérnek, hogy egy, vagy két személy használta az autót. ${ }^{25}$ Abban minden szemtanú egyetért, hogy a feltételezett elkövető (vagy elkövetők) kiszállt az autóból, és egy perccel azután robbant a bomba. ${ }^{26}$ Másrészt a magatartás sem utalt arra, hogy az autót használó személyek tisztában lettek volna azzal, hogy bomba van a kocsiban. Mert a viselkedésük nyugodt volt, az egyik visszaemlékezés szerint a felételezett merénylő telefonált a robbanás

\footnotetext{
23 BOMBS KILL SCORES IN EGYPTIAN RESORT TOWN, 2011.

${ }^{24}$ EgYPT BOMB KILLS 21 AT ALEXANDRIA COPTIC CHURCH, 2011.

25 EGYPT BOMB KILLS NEW YEAR CHURCHGOERS, 2011,

${ }^{26}$ FAHIM, 2011.
} 
bekövetkezte előtt. Valószínűsíthető, hogy a támadás eredeti szándéka szerint nem öngyilkos merénylet lett volna, hanem pokolgépes merénylet. Vélhetően az autót leparkolták volna, majd az időzítőt akkora állították volna, amikor a tömeg a templom előtt gyülekezik a mise után. Ekkor a robbanás jelentôsebb pusztítást is okozhatott volna. Azonban megint az időzítő hibája miatt robbant fel korábban a bomba, akárcsak a 2005-ös tabai merényletnél. Így kevesebb áldozatot szedtek az eredetileg tervezettnél, és a két merénylő is meghalt.

\section{II. ÖNGYILKOS MERÉNYLETEK 2020-IG}

\subsection{A Sínai-félszigeten kirobbant felkelés okairól és az öngyilkos merényletekről 2013 közepéig}

Mubárak hatalmának 2011-ben az Észak-Afrikában és Közel-Keleten kibontakozó, arab tavasz néven ismert tüntetés,- és felkeléssorozat vetett véget. A tüntetéssorozat Tunéziából indult ki, és jelentős hatása volt az arab világra. Az arab tavaszhoz vezető okokról számos átfogó tanulmány és egyéb publikáció született, így itt a teljesség igénye nélkül olyan, az északafrikai és közel-keleti országok jelentős részében általánosnak mondható jelenségek vezettek a megmozdulásokhoz, mint a politikai elégedetlenség, a szociális okok (magas születésszám, nagyarányú munkanélküliség a fiatalkorú és a felnőtt népesség körében, elégtelen életszínvonal, nagyarányú korrupció stb.). Ezeket a tényezőket erősítette fel a mubáraki rendszer elnyomó politikájával szembeni széleskörű elégedetlenség. ${ }^{27}$ Szintén érdemes megemlíteni azt a tényt, hogy Egyiptom vidéki részeirôl nagy számban költöztek fel a fôvárosba, és sokan kényszerültek rossz életkörülmények közé, ráadásul a munkaerő-piac nem volt képes felszívni a megnövekedett számú munkavállalók tömegeit. ${ }^{28}{ }^{29}$ A kormány már az arab tavaszt megelőző évtizedekben is élelmiszertámogatás útján igyekezett ellátni a lakosság jelentős részét, azonban a gazdaságélénkítés céljából Mubárak csökkenteni kezdte az állami hozzájárulások mértékét, így 1986-ban például

\footnotetext{
${ }^{27}$ KHALIFA, 2000.

28 A lakosság 42,5\%-a élt a városokban 2006-ban, ez az arány azonban kis mértékben csökkent. Egyúttal ekkorra vált megfigyelhetővé alacsony mértékben a kivándorlás a városokból, a külvárosok felé, amelyek rohamosan növekedtek 2006-ban 2,6\% arányban. Forrás: WORLDBANK REPORT, 2006., 3-4.o.
}

${ }^{29}$ ENSZ JELENTÉS, 2013. 
Öngyilkos merényletek Egyiptomban a 2004 és 2020 közötti időszakban - Az öngyilkos merényletek elkövetési módjainak vizsgálata szervezettség alapján, a vallás szerepének

figyelembevételével

kenyérlázadás tört ki Egyiptomban. ${ }^{30} \mathrm{Az}$ életszínvonal miatti elégedetlenség olyan mértéket öltött, hogy a tunéziai eseményeket látva az emberek utcára vonultak, és nagy létszámú tüntetéseket tartottak Mubárak ellen. Az elnök a hadsereget vezényelte fel a fővárosba, tőlük várva a tüntetések felszámolását. Erre a hadsereg nem volt hajlandó. Mubárakkal közölték, hogy nincs más megoldás számára, vagy lemond, vagy pedig eltávolítják a hatalomból.

Mubárak az utóbbit választotta, a hatalmat pedig a Fegyveres Erők Legfelső Tanácsa (angol elnevezéssel: Supreme Council of the Armed Forces, rövidítve SCAF) vett át. Eközben a Sínai-félszigeten lázadássorozat söpört végig, amit segített, hogy az a néhány katonai alakulat, amit az Izraellel aláírt békeszerződés helyben engedélyezett, a fővárosba lett vezényelve. A félsziget északi része évtizedekig kvázi senki földje volt. Egyiptom a területet az Izraellel 1979-ben aláirt békeszerződés keretében kapta vissza. Azonban a központi kormányzat nem bízott a helyi törzsekben, mert árulóknak tartották őket. Ezért másodlagos állampolgárnak számítottak, nem lehettek a biztonsági erők tagjai, és nehezen juthattak orvosi ellátáshoz, gyógyszerekhez. Másrészt a területet kevésbé fejlesztették a déli, turisták számára kedvelt célpontnak számító részhez viszonyítva.

Így a félsziget északi térsége rendkívül elmaradott volt. Ezen úgy próbáltak a helyiek változtatni, hogy a Gázai-övezetból csempészték be a félszigetre a szükséges javakat. Az élet kilátástalansága pedig a terrorszervezeteknek kedvezett, akik a törzsek mellé települtek, és jelentős támogatást élveztek a fiatalok között. ${ }^{31} \mathrm{Az}$ első terrorcsoport, a Tavhíd alDzsihád (magyarul az Egyistenhit és Dzsihád) a 2000-es évek elején jelent meg és kezdett toborzó tevékenységbe az itteni fiatalok között. A 2006-os Daba-i merénylet után az egyiptomi erők jelentős antiterrorista tevékenységbe kezdtek a térségben, több férfit, nőt, gyereket tartóztattak le, farmokat romboltak le, állítólag loptak is a helyiektől. Így többen radikalizálódtak a fiatalok közül, és kerültek a terrorcsoportok befolyása alá. ${ }^{32}$

Ezért amikor az arab tavasz miatt kirobbant tüntetések hatására a hadsereg helyben állomásozó alakulatait a fővárosba vezényelték, a helyi lakosok fellázadtak, rendőrőrsöket támadtak meg és fegyvereket zsákmányoltak. A lázadás pedig a félsziget egészét érintette. A hadsereg

\footnotetext{
${ }^{30}$ KIFNER, 1986.

${ }^{31}$ IDRIS, 2017. 3.o.

32 AZIZ, 2017.
} 
csapatokat küldött a területre, akik megpróbálták pacifikálni azt, sikertelenül. ${ }^{33}$ Több támadást, merényletet követtek el egyének a katonák ellen. Ezek a támadások általában ad hoc jellegủek voltak, és inkább fegyveres rajtaütésként kerültek végrehajtásra. Öngyilkos merényletek nem voltak jellemzőek a 2011-2013 közötti időszakban. Az előbb említett periódusban csak egy öngyilkos merényletet hajtottak végre a Sínai-félsziget északi részén a határ közelében. Mindez azután következett be, miután a terroristák a határt átlépve egy izraeli buszt támadtak meg, amely katonákat szállított. A busznak sikerült egy katonai ellenőrző ponthoz érkeznie. Ezután az izraeli haderő és rendőrség kiérkezett alakulatai üldözni kezdték a terroristákat, közülük többel végeztek. Az egyik terroristának sikerült átkelnie a határon, ahol az egyiptomi ellenőrző pontnál felrobbantotta magát, több katonát megölve. ${ }^{34}$ A kétéves ciklus alatt csak egy öngyilkos merényletet hajtottak végre, míg gépfegyveres támadások rendre érték az egyiptomi katonákat. Ebben közrejátszhatott az, hogy a terrorcsoportok még nem voltak eléggé szervezettek, kevés emberük volt, így inkább a kisebb gépfegyveres támadásokat választották. Másrészt, ezt vallási okokkal is magyarázhatjuk.

Egyiptomban a Muszlim Testvériség 2012-es választási győzelmét a Sínai-félszigeten ünnepelték. Úgy vélték, hogy Egyiptomnak végre olyan kormányzata lehet, amely a vallást is képviseli, és a hadseregnél kevésbé elnyomó. Ezért sem alkalmaztak öngyilkos merényletet a katonák ellen, mivel azt általában a más vallású célpontok ellen vetették be. Eddigi vizsgálódásaink ugyanis arra mutattak, hogy a Mubárak-korszakban gyakran vallási alapon alkalmaztak öngyilkos merényletet, főleg turisztikai célpontok ellen. Így a vallás is fontos szemponttá vált ezek végrehajtásában, amit a muszlimok ellen nem követtek el. Így a hadsereg erőit sem érte öngyilkos merénylet, az imént említett egy esetet kivéve.

A katonákat ért támadásokról összességben elmondható, hogy nem voltak jól kidolgozva, kisebb rajtaütések formájában kerültek végrehajtásra, és a hadsereg erői gyorsan eliminálták a merénylőket. ${ }^{35}$ Mindez arra enged következtetni, hogy egyrészt a katonai beavatkozás ellen ekkor még a helyiek harcoltak, akik nem alkalmaztak öngyilkos merényletet, mert nem akarták megölni magukat. Másrészt a terrorcsoportok is kivették a részüket a támadásokból, azonban nem volt meg a megfelelő infrastrukturális,

\footnotetext{
${ }^{33}$ KATZ, 2011.

34 ISSACHAROFF, 2011.

35 HALAWI, 2011.
} 
Öngyilkos merényletek Egyiptomban a 2004 és 2020 közötti időszakban - Az öngyilkos merényletek elkövetési módjainak vizsgálata szervezettség alapján, a vallás szerepének

figyelembevételével

parancsnoki hátterük, sem pedig nem volt elég emberük ahhoz, hogy nagyobb, és jobban kidolgozott támadásokat hajtsanak végre.

\section{2. Öngyilkos merényletek a Szíszi-korszakban}

A Mohamed Murszi vezette Muszlim Testvériség uralmának AbdelFattáh al-Szíszi tábornagy, hadügyminiszter beavatkozása vetett véget. A Muszlim Testvériséget azért kellett félreállítani, mert a szervezet korrupt volt, az iszlám vallás törvényeit igyekeztek minél inkább bevonni az alkotmányba, és a hatalmi ágak mindegyikébe a saját embereiket ültettték. Azonban a szervezet tevékenysége az egyiptomi társadalom jelentős része számára inkább visszatetszést keltett, ezért 2013 júniusában tüntetések szerveződtek Kairóban. Erre válaszul a hadsereg bejelentette, hogy az elnöknek le kell mondania a hivataláról. Ha nem teszi, akkor el fogják távolítani a pozíciójából. Murszi erre nem volt hajlandó, azt hangoztatva, hogy ő a demokratikusan megválasztott egyiptomi elnök. Így 2013. július 3án az egyiptomi hadsereg leváltotta ôt és ideiglenesen Adli Manszúrt helyezte az elnöki székbe. Azonban a katonai hatalomátvétel ellen jelentős tüntetések robbantak ki augusztusban a kairói Rábia al-Adavijja és a Nahda téren. Ezeket a hadsereg erőszakkal fojtotta el, 638 ember meghalt, többszázan pedig megsebesültek. ${ }^{36} \mathrm{Ez}$ pedig hozzájárult a Sínai-félszigeten folyó harcok kiéleződéséhez. Mint már említettem, a Sínai-félszigeten az emberek elfogadták a Muszlim Testvériség kormányzását. Úgy vélték, hogy végre őket is képviseli az állam. ${ }^{37}$ Azonban a hatalomátvétel, és a tiltakozások vérbe fojtása aktivizálta a Sínai-félszigeten lévő terrorcsoportokat is. Így ezek már nemcsak lövöldözéses támadásokat, de öngyilkos merényleteket is végrehajtottak. Ezek mennyisége a korábban végrehajtottak többszörösét tették ki. Itt szeretnék egy pillanatra visszautalni a korábban leírtakra.

\footnotetext{
36 FAYED, 2016.

${ }^{37}$ FISHER, 2013.
} 


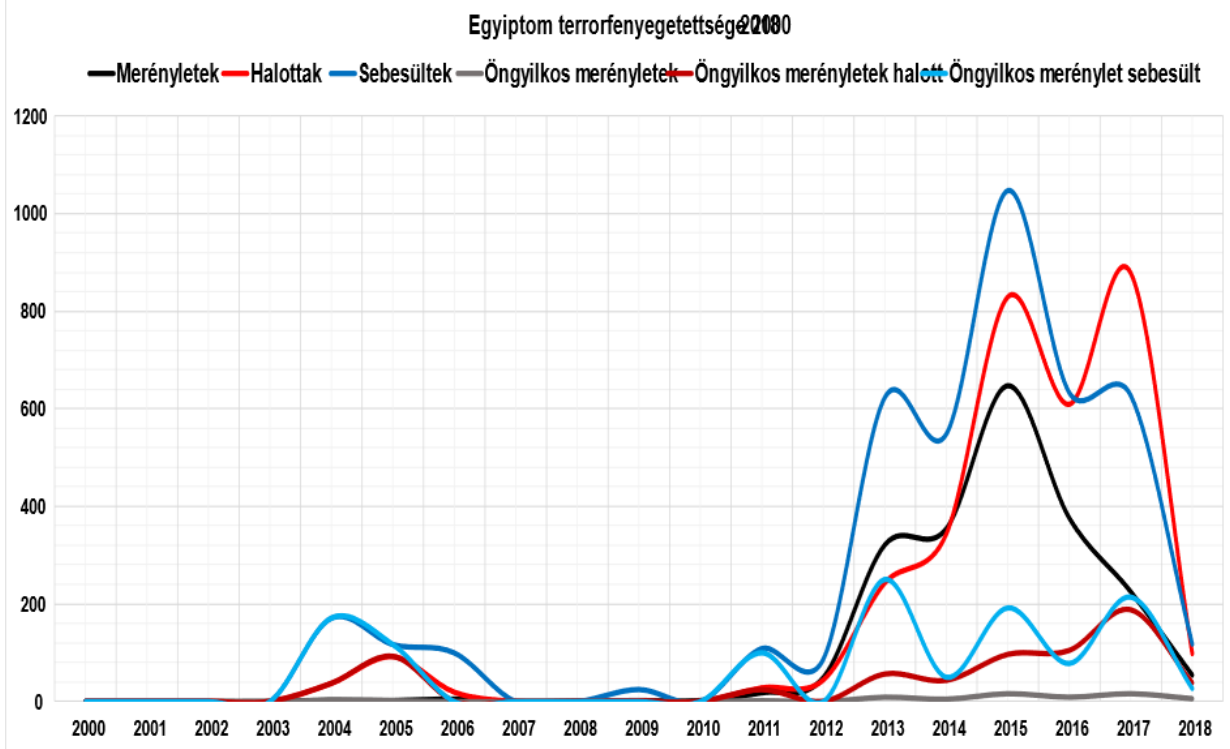

Egyiptomi terrorfenyegetettség 2000-2018 között. Forrás: Global Terrorist Database

Mubárak elnökségének (2005-2011) utolsó öt évében csak három olyan esztendőrôl tudunk, amikor egynél több merényletet hajtottak végre: 2004-ben hármat, míg 2005-ben és 2011-ben pedig kettôt-kettőt. Az itt említett merényletek közül csupán egy-kettő minősül tényleges öngyilkos merényletnek, terrorcsoport által végrehajtott merényletről pedig egyrôl tudunk. A Mubárak-rendszer bukása és a katonai hatalomátvétel között pedig csak egy öngyilkos merényletet hajtottak végre terrorcsoportok 2011. augusztus 19-én. Vizsgáljuk meg a számok tükrében a Szíszi-féle hatalomátvétel után történt időszakot. 2013 második felében kilenc öngyilkos merényletet követtek el, 2014-ben ötöt, 2015-ben 16-ot, 2016-ban szintén 9-et, 2017-ben 16-ot, míg 2018-ban összesen hatot. 2019-ben viszont, csak kettőt lehet biztosan öngyilkos merényletként elkönyvelni, 2020-ban pedig egyáltalán nem történt öngyilkos merénylet. Vajon mi lehet az oka annak, hogy a Szíszí-korszak alatt ilyen sok öngyilkos merénylet történt zömében a Sínai-félszigeten?

Talán az egyik legfontosabb tényező ebben magában a 2013-as hatalomátvételben keresendő. Mivel a katonai hatalomátvétel közben 
Öngyilkos merényletek Egyiptomban a 2004 és 2020 közötti időszakban - Az öngyilkos merényletek elkövetési módjainak vizsgálata szervezettség alapján, a vallás szerepének

figyelembevételével

jelentôs erőszakot alkalmaztak muszlim tüntetőkkel szemben, és egy deklaráltan muszlim elvek mentén múködő kormányzatot távolítottak el, ezért a félsziget lakossága szemében az új kormány muszlim identitása megkérdőjeleződött. Így a terrorcsoportok anélkül követhettek el öngyilkos merényletet, hogy azt komolyabban indokolniuk kellett volna. Ne feledjük, a korábbi támadások főként turisztikai célpontok ellen következtek be, amelyeket könnyű volt támadni, de ahol főként a más vallási felekezethez tartozó turisták jártak. A legjelentősebb támadásokat korábban 2004-2005ben a Sínai-félsziget déli részén olyan célpontok ellen valósultak meg, amelyeket izraeli állampolgárok látogattak. Hipotézisem szerint a külföldi, más felekezeti háttérrel rendelkező személyek ellen elkövetett merényletek mögött volt vallási motiváció is, amely indokolhatta az ilyen nagy pusztítást okozó, és a merénylő életét is kioltó támadások végrehajtását. Másrészt az öngyilkos merényletek számának növekedésében szerepet játszhatott a félszigetre áramló emberutánpótlás is, amelyet volt börtönviseltek, és korábbi Muszlim Testvériség tagok alkothattak. Ezek az elemek vagy már eleve szélsőségesek voltak, vagy a börtönben, esetleg a hatalomátvételt követő elégedetlenség következtében radikalizálódtak. ${ }^{38}$ Ennek következtében a volt tagok létrehoztak terrorszervezeteket (az egyiptomi hatóságok szerint a HASM (Ḥarakat Sāwa'd Mișr, Egyiptom Fegyveresei) is ilyen terrorcsoport lehet), illetve más csoportokba is kerülhettek. ${ }^{39}$

Ezen túlmenően az öngyilkos merényletek számának jelentős változását az is előidézte, hogy az Anszár Bajt al-Makdísz (Jeruzsálem védelmezői) nevű terrorszervezet hűséget esküdött az Iszlám Államnak. Így a szervezet új formában, mint az Iszlám Állam Sínai Vilájete létezett tovább. ${ }^{40}$ Természetesen a hűségeskü új embereket és jelentôs gazdasági támogatást jelentett a szervezet számára. Az új tagok főleg az Egyiptomot Palesztinával összekötő csempészalagutakon keresztül érkezhettek az országba. Ők honosították meg azokat a taktikai elemeket, amiket az Iszlám Állam használt a szír hadsereg ellen. Erre példa, hogy a kisebb rajtaütéseket gyakran kombinálták öngyilkos merényletekkel, amely jelentős pusztítást okozott az egyiptomi hadsereg katonái körében. ${ }^{41}$ Új elemként jelent meg az, hogy a szervezet erőszakot alkalmazott a lakossággal szemben. A hűségesküt megelőzően az elődszervezet nem lépett fel erőszakosan a helyi

\footnotetext{
38 MUSLIM BROTHERHOOD FORMED 13 TERRORIST GROUPS IN EGYPT: NGO, 2020.

${ }^{39}$ US SANCTIONS EGYPT'S HASM, TARGETS ISIS-AFFILIATE, 2021.

40 SinAi PROVINCE: EgYPT'S MOST DANGEROUS GROUP, 2016.

${ }^{41}$ SINAI SECURITY STYMIED BY CONTINUED TERRORIST ATTACKS, 2015.
} 
civilekkel szemben, mert támogatást remélt tőlük. Az átalakult csoport azonban kegyetlenül bánt a törzsekkel és a helyi lakossággal is. Valószínúleg úgy vélték, hogy összejátszanak az egyiptomi hadsereggel, illetve szerették volna ezt a kegyetlen bánásmóddal megakadályozni.

Az Iszlám Állam egyik szárnyaként a Sínai Vilájet igyekezett a Koránban lefektetett vallási előírásokat fenntartani a területén. Így gyakran állítottak fel ellenőrző-áteresztő pontokat, amelyen keresztül ellenőrizték a lakosság öltözetét vagy szokásait. ${ }^{42}$ A vétkeseket megbüntették. Emberrablásokat is végrehajtottak; általában egyiptomi tisztviselőket raboltak el.

Az öngyilkos merényleteket is különböző módon hajtották végre. Egyik legjellemzőbb, klasszikus módszer, amikor általában autóba rejtett pokolgépet robbant fel a benne ülő merénylő. A támadást általában ellenőrző-áteresztő pontok mellett, vagy járőrtevékenységet folytató rendőrök-katonák ellen hajtottak végre. Ez történt 2015. november 4-én is, amikor egy autóba rejtett pokolgépet robbantott fel a merénylő a Sínaifélsziget északi részén. A támadást a Sínai Vilájet vállalta magára, amit azzal indokoltak, hogy a félszigeten a hadsereg több nőt tartóztatott le. A terrorcsoport a támadások kezdetekor is öngyilkos merényletet követhetett el. Ekkor főleg ellenőrző-áteresztő pontok ellen követtek el merényletet, és igyekeztek zûrzavart kelteni az üzemeltető katonák között. Így a teljes felfordulásban a gépfegyveres támadók nagyobb pusztítást voltak képesek okozni a biztonsági erők tagjai között. Erre példa a 2015. április 12-ei Obaídat bázis elleni támadás is. Ennek során autóba rejtett pokolgéppel igyekeztek elvonni a bázis őreinek figyelmét. Az őrök a merénylővel együtt lőtték ki a kocsit, azonban nem vették észre, hogy a támadás közben a szélsőségesek a bázishoz közeli magaslati pontokat elfoglalták. Ezekből a pontokból érkezett a támadás, amely sok katona életét követelte. ${ }^{43}$

Ennek az ellenkezője is előfordult. 2018. április 14-én támadás érte a Kaszíma laktanyát. Ekkor a merénylők a kerítést felfeszítve tudtak bejutni az objektumba. Ezután gépfegyveres támadással okoztak káoszt a katonák között. A fennforgás közben pedig öngyilkos merényletet alkalmaztak, amivel maximalizálni tudták az áldozatok számát. A hadsereg a támadás után 8 fó halált ismerte el, azonban a terroristák, és a helyiek szerint az áldozatok száma elérte a 20 főt. $^{44}$ Mint látható, a merényletek nagyon

\footnotetext{
42 Hassan, 2017.

43 SINAI SECURITY STYMIED BY CONTINUED TERRORIST ATTACKS, 2015.

${ }^{44}$ MOHAMAD, 2019.
} 
Öngyilkos merényletek Egyiptomban a 2004 és 2020 közötti időszakban - Az öngyilkos merényletek elkövetési módjainak vizsgálata szervezettség alapján, a vallás szerepének

figyelembevételével

rugalmasak voltak, és igyekeztek kihasználni az egyiptomi hadsereg gyengeségeit. Valószínú, hogy ezeket volt katonák tervezhették, illetve ebben az Iszlám Állam harcosai is szerepet vállalhattak. Ilyen volt katonára lehet példa Heshám Ásmavi, aki korábban az Anszár Bajt al-Makdísz soraiban harcolt. Azonban, amikor a csoport az Iszlám Állam tagja lett, akkor kilépett, és Líbiában alapított újabb terrorszervezetet. Azonban Haftar tábornok hadmúveletei során elfogták, és átadták Egyiptomnak, 2020-ban pedig kivégezték. ${ }^{45}$

A szervezet vezetésében azonban drasztikus visszaesés következett be 2016-ban, amikor az egyiptomi haderő lebombázta a Sínai Vilájet felső vezetését a Halal-hegységnél. ${ }^{46} \mathrm{Ez}$ egy ideig rontotta a szervezet műveleteinek hatékonyságát, azonban, mint látható, 2018-ban ismét hatékony támadásokat voltak képesek végrehajtani. Ez véleményem szerint annak volt köszönhetô, hogy sikerült újabb harcosokat átcsempészni Palesztinából, valamint az ellenőrizetlen líbiai határon át, így a Sínai Vilájet ismét utánpótláshoz juthatott. A csoport 2016 végén, 2017 elején veszített a területeiből és a hatékonyságából. Ez köszönhető volt a hadsereg műveleteinek, valamint az Iszlám Állam visszaszorulásának. Így újra a koptok lettek a terrorista támadások célpontjai. Ezeknek a merényleteknek a célja vélhetôen az volt, hogy vallási konfliktust hozzanak létre a felekezetek között, és így növeljék a népszerüségüket a vallások és felekezetek közti harcra fogékony emberek között. 2017. április 9-én két öngyilkos merényletre került sor Alexandriában és Tantában, ahol éppen virágvasárnap alkalmából tartottak miséket. Tantában a merénylőnek sikerült átjutnia a biztonsági erők által felállított kordonon, és felrobbantania magát a székesegyház előterében, megölve 28 embert és 77-et megsebesítve. ${ }^{47}$ Alexandriában is megpróbálkozott a támadó átjutni a kordonon, azonban ôt az egyik fémdetektoros kapu felé irányították. Itt az egyik tiszt megállította, ekkor pedig felrobbantotta magát. 17 embert ölt meg, és 48-at megsebesített. A merényletek után a biztonsági erők kemény kritikákat kaptak a székesegyházak ellenőrzésével kapcsolatban. Sok kopt úgy vélte, hogy nem ellenőrizték kellőképpen a templomokat, pedig korábban is voltak hasonló támadások. ${ }^{48}$ Egy héttel korábban ráadásul egy bombát hatástalanítottak közel az alexandriai székesegyházhoz. Így a

\footnotetext{
45 EgYPT EXECUTES ISLAMIC EXTREMIST HESHAM ASHMAWY, 2020.

46 SCHWEITZER, 2016.

${ }^{47}$ EGYPT'S COPTIC CHURCHES HIT BY DEADLY BLASTS ON PALM SUNDAY, 2017.

${ }^{48}$ HENDAWI, 2017.
} 
támadásra számítani lehetett volna. A koptok szerint, bár az állam azt állítja, hogy megvédi őket, de valójában nem tesz semmit, és így ki vannak szolgáltatva a szélsőséges támadásoknak.

A merénylet után egyébként utcai zavargásokra is sor került a keresztények részéről, akik a kormányzati védelem elégtelenségét kifogásolták. Egyébként bár az állam azt hangsúlyozza, hogy a koptok is ugyanolyan állampolgárnak számítanak, mint muszlim társaik, a gyakorlatban ez nem így van. Ôk sem lehetnek például a biztonsági erôk tagjai, és az államigazgatásban sem tölthetnek be magas rangú hivatalt. Ráadásul, bár az egymást követő kormányzatok gyakran hangoztatták, hogy megvédik őket a szélsőségesektől, eddig erre kevés példát láttunk. ${ }^{49}$ Olyan azonban előfordult, hogy a biztonsági erôk tagjai engedtek be rongálókat kopt szentélyekbe. Így lényegében a koptok már nehezen fogadják el II. Teodor pátriárka kinyilatkozásait, amelyben az egyiptomi állammal való együttmúködést szorgalmazza. ${ }^{50}$ Jelenleg a kopt egyházon belül van egy nagyobb csoport, amely kritikával illeti annak együttmúködését az állammal. Nem lehet tudni, hogy a folyamat meddig tart, de elképzelhető hosszútávon az egyházszakadás is.

A terroristák másik kedvelt célpontjává a turisták váltak, akik 2015től kezdve ki vannak téve támadásoknak. Ennek az az oka, hogy a terrorszervezetek rájöttek arra, hogy nem képesek a hadsereget legyőzni, ezért a turisták ellen fordultak. Úgy vélték, hogy képesek olyan gazdasági károkat okozni, amely majd megrengeti az egyiptomi államot. Legfőképpen pokolgépes merényleteket (gízai piramisok mellett két támadás is volt az elmúlt négy évben), ${ }^{51}$ illetve lőfegyveres támadásokat hajtottak végre ellenük.

Öngyilkos merényletek kevésbé voltak jellemzőek, tekintve, hogy a katonák jobb célpontot nyújtanak a turistáknál. Ám ennek az ellenkezôjére is volt példa. 2015. október 16-án három fegyveres kísérelt meg megtámadni egy turista buszt a Karnak-templomnál, Luxorban. Azonban, mielőtt a merényletet végrehajthatták volna, a helyszínt őrző biztonsági személyzet közbelépett. İgy az öngyilkos merénylő a biztonságiak érkezésére felrobbantotta magát, két társát pedig lelőtték, egyikük súlyosan megsérült. ${ }^{52}$ A támadás után más öngyilkos merényletet turisták ellen nem találtam. Vélhetően azért, mert a terrorszervezeteket túlságosan lefoglalta a harc a

\footnotetext{
49 HANNA, 2019.

${ }^{50}$ FARID, 2018.

${ }^{51}$ EGYPT EXPLOSION: TOURISTS ON BUS INJURED NEAR GIZA PYRAMIDS, 2019.

52 MALSIN, 2015.
} 
Öngyilkos merényletek Egyiptomban a 2004 és 2020 közötti időszakban - Az öngyilkos merényletek elkövetési módjainak vizsgálata szervezettség alapján, a vallás szerepének

figyelembevételével

hadsereg erőivel szemben. Így nem akarják pazarolni az élőerőt olyan célpontok ellen, amelyeket megfelelő védelemmel láttak el effajta támadások ellen.

Végezetül előfordulnak olyan öngyilkos merényletek (csakúgy, mint Mubárak alatt), amelyek véletlenül, a merénylő akaratán kívül következnek be. Erre akkor van esély, amikor a támadót megfigyelik, és meglepik, ezért az felrobbantja magát. Ez történt 2019. február 19-én is, amikor az elkövető robbantotta fel magát, miután a rendőrség üldözni kezdte. Már egy hete figyelhették, mivel őt gyanúsították, hogy bombát helyezett el egy kairói mecsetnél. Február 19-én viszont a robbantó észlelte, hogy követik, ezért menekülni kényszerült. Mivel kilátástalannak ítélte a helyzetét, ezért inkább felrobbantotta magát. A merényletben három rendőr halt meg. ${ }^{53}$ Mint látható, még mindig vannak olyan öngyilkos merényletek, amelyek nem tervezés, hanem a merénylő szorult helyzete miatt, rögtönzés következtében történnek meg. Bár a Mubárak-korszak alatt az öngyilkos merényletek jelentôs része a nem elôre eltervezett merényletek kategóriájába esett, azonban 2013-tól kezdve ez visszaszorult. Ennek az volt az oka, hogy ezeket a támadásokat már terrorszervezetek hajtották végre, akik valamilyen taktikai/ideológiai terv mentén alkalmazták azokat. Így az elkövetők is főleg ezeknek a szervezeteknek a köréből kerültek ki. A 2018-as terroristák elleni hadműveletekig lehetett szervezett öngyilkos merényletekről beszélni, az elmúlt évek során pedig ad-hoc merényletek kerültek végrehajtásra, ami a terrorszervezetek visszaszorulásának lett a következménye. Ezek a merényletek a városokban nem igazán jellemzőek, ahol inkább pokolgépes merénylettel, vagy fegyveres támadással igyekeznek sikert elérni. ennek az az oka, hogy a városi szervezetek néhány főt számlálnak csupán, így a fennmaradásuk érdekében az öngyilkos merényleteket mellőzniük kell. Azonban a fenti merényletnél nem lehet pontosan tudni, hogy a támadó melyik szervezethez tartozott. Lehetséges, hogy egyéni merénylő volt. Valószínűleg pokolgépes támadásra készült, amit végül lefüleltek, ezért döntött az öngyilkos merénylet mellett.

Az öngyilkos merényletek száma 2018-tól kezdve meredeken zuhant, 2020-ban pedig egyáltalán nem volt jellemző az országban. Mi lehet ennek az oka? Egyiptom jelentős katonai műveletet indított el 2018-ban a Comprehensive Military Operation (Széleskörű Katonai Művelet) néven. A műveletet azután indították, miután 2017. november 24-én a Sínai Vilájet

${ }^{53}$ EGYPT: SUICIDE BLAST IN CAIRO TOURIST AREA KILLS THREE POLICEMEN, 2019. 
támadást indított az al-Ravda mecset ellen a Sínai-félsziget északi részén. ${ }^{54} \mathrm{~A}$ mecset az iszlám szúfi ágához tartozók imádkozó helye volt, ami a terrorszervezet szemében az iszlám nem kívánatos vallási iskolájához tartozott. Így a csoport stratégiájával összhangban megtámadták, mert úgy vélték, a támadás üzenet lesz majd a más vallási irányzatot képviselőknek. A merényletet nagyrészt gépfegyveres támadók követték el, de ebben pokolgépeket is használtak. A támadásban 235-en vesztették életüket. Azonban a cselekmény fordulópontnak bizonyult. Egyrészt az egyiptomi vezetés eltökélte, hogy leszámol a terroristákkal. Másrészt a Sínai Vilájeten belül is éles vitákat váltott ki a támadás, volt, aki otthagyta a szervezetet. Így az egyiptomi hadsereg jelentős erőkkel vonult be a félszigetre, amelyet teljesen lezártak a ki és bemenő forgalom elől. ${ }^{55}$

Így igyekeztek megszüntetni a terrorszervezetek élőerő, és fegyverutánpótlását, valamint megakadályozni merényletek végrehajtását a belső területeken. Közben nagyobb műveletekkel kisöpörték a terrorcsoportokat, és tagjaikat letartóztatták, vagy megölték. Folyamatos járőrtevékenységet folytattak, és oda csoportosították az erőiket, ahol nagy szükség volt rájuk. ${ }^{56}$ Közben nemcsak katonai eszközöket használtak, hanem megjelentek a térség gazdasági fejlesztését célzó programok is. Jelenleg a helyiek életszínvonalának növelése a cél. A múlt évben jelentős gondot fordítottak a csatornázásra, igyekeztek víztározókat kialakítani, illetve olyan új módszereket bevezetni, amelyek csökkentik a felesleges vízfogyasztást. ${ }^{57}$ A lakosságnak pedig új, összeszerelhető lakhelyekkel igyekeznek segíteni. Mindez annak az új fejlesztési programnak a része, amelyet a kormányzat néhány éve jelentett be. Ennek fó célja a Sínaifélsziget északi részének fejlesztése. Ez a program azért fontos, mert a 2011es lázadások egyik fő kiváltó oka a régió gazdasági fejletlensége, és az ebből eredő elégedetlenség volt. A helyiek úgy érezhették, hogy a kormányzat nem törődik velük. A program fő célja valójában az, hogy a terrorista csoportokat leválassza a helyi lakosságról. ${ }^{58}$ Azonban kérdéses ennek sikere, mivel jelentős emberi jogi visszaélésekre panaszkodtak a helyiek. És bár a hadsereg jelentős letartóztatásokat foganatosított a félszigeten, azonban ezek nagyrésze olyan embereket ért, akiknek a kapcsolata a

\footnotetext{
${ }^{54}$ EgYPT ATTACK: GUNMEN KILL 235 IN SINAI MOSQUE, 2017.

55 MANDOUR, 2018.

56 MCMANUS, 2020.

57 President Sisi REVIEWS PROGRESS OF SinAi DEVELOPMENT PROJECTS, 2020.

58 ZAID, 2020.
} 
Öngyilkos merényletek Egyiptomban a 2004 és 2020 közötti időszakban - Az öngyilkos merényletek elkövetési módjainak vizsgálata szervezettség alapján, a vallás szerepének

figyelembevételével

terrorszervezetekkel erősen megkérdőjelezhető. Ez pedig bizonytalanná teheti a gazdasági programok sikerét, hiszen a fejlesztések ellenére a lakosság bizalmát nem biztos, hogy el tudják nyerni a biztonsági erők terrorellenes hadjáratának támogatása érdekében.

A múvelet óta a nagyobb merényletek száma jelentős mértékben csökkent. Bár a 2018-2019-es években is hallunk nagyobb, néhány fő veszteséggel járó öngyilkos merényletekről, ezek mára elenyészővé váltak. 2020 végén már olyan híreket is lehetett olvasni, amelyek megváltozott végrehajtásokról számolnak be. ${ }^{59} \mathrm{~A}$ hadsereg mûveletei következtében a terrorszervezetek annyira kivéreztek, hogy nagyobb támadások megszervezését már nem tudják vállalni. Ezért áttértek az egyénileg elkövetett műveletek alkalmazására. A közeljövőben számolni kell egyének által elkövetett gépfegyveres cselekményekkel, pokolgépes merényletekkel, ${ }^{60}$ késes támadásokkal, esetleg orvlövészek tevékenységével. Ezek a típusú merényletek már jóval nehezebben kezelhetőek. Míg korábban a terrorszervezetek búvóhelyeit fel lehetett deríteni, és esetleg likvidálni, vagy letartóztatni a tagjaikat, az mára már nem lehetséges, mivel a terrorcsoportok tagsága lecsökkent, és a helyiek között próbálnak eltűnni. Ennek köszönhetően könnyebben is közlekedhetnek a merényletek célpontjai között. Közben az ismert tagokat letartóztatták, és olyan vezetők kerültek a helyükre, akiket a hatóságok még nem ismernek. Ezek a problémá pedig csak a lakosság támogatásával megoldható. Azonban, mint már korábban említettem, ennek gátat vethet a biztonsági erôk korábbi tevékenysége a lakosság körében.

\section{KONKLÚZIÓ}

Tanulmányomban az egyiptomi öngyilkos merénylettekkel kapcsolatban igyekeztem válaszokat találni. Az egyik legfontosabb kérdés, hogy miért csak Mubárak uralmának utolsó éveiben jelentkeztek? Ennek az volt az egyik fő oka, hogy öngyilkos merényleteket az 1980-as évek előtt nem igazán alkalmaztak, csak a libanoni polgárháború után lett elfogadott eszköz a terroristák körében. A rendszer pedig igyekezett a szélsőséges szervezeteket ellenőrzése alatt tartani, és a támadásaikat kíméletlenül

59 EGYPT: SHIFTING TACTICS BY ARMED GROUPS CURB SINAI DEVELOPMENT, 2020.

60 2021. január 1-jén ilyen merénylet végzett a biztonsági erôk két tagjával. Ez a támadás már a harmadik volt a sorban, a korábbiakat az előző év decemberében követték el. Forrás: EGYPTIAN OFFICIALS: ROADSIDE BOMBING IN SINAI KILLS 2 POLICE, 2021. 
megtorolták. Egyébként a különböző elnökök más-más eszközöket alkalmaztak velük szemben. Nasszer és Mubárak igyekezett teljes kontroll alatt tartani őket, és még a vallást is felhasználták ellenük. Szadat politikájában megfigyelhető egy váltás ezzel kapcsolatban, de ez csak elnöksége első szakaszára igaz. Ekkor a nasszeri ellenzék felszámolásához szüksége volt a vallási szervezetek támogatására. Így azok újra részt vehettek a politikai-szociális szférában. Azonban a Muszlim Testvériség korábbi szélsőséges tagjai, és azok, akik Szaúd-Arábiába menekültek, beszivárogtak ezekbe a szervezetekbe. Ezek pedig kezdtek szélsőségessé válni, így végül Szadat is nyomás alá helyezte őket. Így a vallási csoportoknak, szervezeteknek nem volt lehetőségük öngyilkos merénylet végrehajtására. A változás a 2000-es évek után érkezett. A szeptember 11-ei események eredményeként a terrorizmus globálissá vált, és az öngyilkos merényletek a hírek szereplőivé váltak. Véleményem szerint ez a változás inspirálhatta a későbbi támadásokat is. Azt is le szeretném szögezni, hogy a merényletek kis hányadánál lehet bizonyítottan állítani, hogy öngyilkos merénylet történt. Az esetek többségében ezek a támadások a „véletlen” miatt váltak öngyilkos merényletté (rosszul összeszerelt bombák, megzavarták a támadót stb.). Másrészt terrorszervezet is bizonyíthatóan csak az egyik támadás mögött állt. A merényletek főleg a turistákat célozták, aminek egyrészt vallási okai (főleg keresztény és zsidó célpontok által látogatott helyeket támadtak meg), másrészt gazdasági okai voltak (igyekeztek elűzni a turistákat, és így bevételkiesést okozni az államnak).

Mindez az arab tavasz után megváltozott. Azonban 2013-ig egy öngyilkos merényletet hajtottak végre az egyiptomi-izraeli határon. Mint azt korábban megállapítottam, a támadások elmaradásának oka a Muszlim Testvériség hatalomra jutásában keresendő. A Sínai-félszigeten a helyi lakosság, és terrorszervezetek szimpatizáltak a Testvériséggel, ezért a biztonsági erők ellen nem követtek el öngyilkos merényletet. Mivel ezek mögött a merényletek mögött sokszor húzódik meg vallási ok, ezért az azonos vallási felekezethez tartozók ellen nem alkalmazzák.

Később azonban a hadsereg által elkövetett brutális hatalomátvétel meggyőzhette a félszigeten a terrorszervezeteket és a lakosságot arról, hogy a katonai kormányzat pogány és a harc velük szemben megengedhető. Ettől kezdve már több öngyilkos merényletet is végrehajtottak a biztonsági erôk ellen. Az öngyilkos merényletek másik forrása az Iszlám Állam lehet. Miután az Anszár Bajt al-Makdísz hűséget fogadott a terrorszervezetnek, a Sínai Vilájet soraiban már a szíriai, iraki harcot megjárt harcosok is lehettek. Az 
Öngyilkos merényletek Egyiptomban a 2004 és 2020 közötti időszakban - Az öngyilkos merényletek elkövetési módjainak vizsgálata szervezettség alapján, a vallás szerepének

figyelembevételével

öngyilkos támadások a félszigeten ugyanis nagyon hasonlóak azokhoz, amelyeket az Iszlám Állam is alkalmazott a szír és iraki erők ellen. Ahhoz, hogy a szervezet ilyen múveletet tudjon végrehajtani, nagy élőerőre van szüksége. Ezt az elégedetlen félszigeti lakosságtól, illetve az ide menekült, korábbi Muszlim Testvériség tagjai közül verbuválhatta. Illetve a múveletek tervezésében és végrehajtásában volt katonák is lehettek a csoport segítségére.

A végrehajtott múveletek is széles skálán mozogtak. A 2013-2018 közötti időszakban a legtöbb öngyilkos merényletet a biztonsági erők tagjai ellen követhették el, mivel ôk végeztek műveleteket a szervezetek ellen. A terrorsejtek számára 2015-től világossá vált, hogy a hadsereget magát nem tudják legyőzni, így a turizmust is célba vették. Azonban kevés öngyilkos merényletet követtek el turisztikai célpontok ellen. Ennek az volt az oka, hogy ezeket a kormányzat megfelelőképpen ellenőriztette, így egy öngyilkos merénylet nem tudott olyan pusztító lenni, mint azt a csoportok remélhették volna. Bár próbálkoztak, de az általam említett példából is kitűnik, hogy nem sikerült a látványosságokat őrző személyzeten átjutniuk, így a védőzónán kívül robbantották fel magukat. Előfordult olyan merénylet is, amely nem szándékosan vált azzá. Ekkor a merénylőt meglephették, vagy korábban megfigyelték, így nem maradt más választása, mint hogy felrobbantotta magát. Azonban ennek száma is elenyésző a Mubárakkorszakhoz viszonyítva. Mindez azért lehetséges, mert az öngyilkos merényletek döntő része továbbra is a Sínai Vilájet alá tartozott, akik igyekeztek ezekkel maximális pusztítást okozni. Illetve a Mubárakkorszakban a terrorcsoportokat próbálták ellenőrzés alatt tartani, így a merényleteket kívülálló merénylők egy csoportja követte el, akik házilag barkácsolt eszközökkel dolgoztak. Ezek azonban sokszor voltak pontatlanok, így a pokolgépes támadások válhattak öngyilkos merényletekké.

2017-től azonban a merényletek száma csökkent. Ez köszönhető volt a Sínai Vilájet vezetői likvidálásának, a 2018-as Comprehensive Military Operation elindításának, és az eddigi gazdasági fejlesztéseknek. Ezen okok miatt 2019-ben csak néhány öngyilkos merényletet hajtottak végre, ezek 2020-ban pedig teljesen eltűntek.

A 2020-as évtől kezdve valószínűleg az egyénileg elkövetett merényletek kerülnek majd ismét előtérbe, amelyek ellen nehezebb védekezni, mint a korábbi csoportos támadások ellen. Így a biztonsági erők a helyi lakosságra lesznek utalva. Ezért szükségesek a fejlesztések, mert ezek 
segítségével a lakosságot meg lehet nyerni, ők pedig segíthetnek a merénylők kézre kerítésében. Azonban kérdésessé teheti az együttmúködést, hogy a hadsereg több erőszakos cselekményt követett el a helyi lakosság ellen, akik nem biztos, hogy a jövőben együttmúködnek velük.

\section{FELHASZNÁLT IRODALOM}

AByAD, AMr-EL (2015): Has Al-Azhar Stifled Egypt's Intellectual Enlightenment?, Egyptian Street. Letöltés helye: https:// egyptianstreets.com/2015/07/27/has-al-azhar-stifled-egyptsintellectual-enlightenment/ (Letöltve: 2021.10.09.)

AZIZ, SAHAR (2017): De-securitizing counterterrorism in the Sinai Peninsula, Brookings.edu. Letöltés helye: https://www.brookings.edu/research/de-securitizing-counterterrorismin-the-sinai-peninsula/ (Letöltve: 2021.11.07.)

BOMBS KILL SCORES IN EGYPTIAN RESORT TOWN (2011) CNN. Letöltés helye:

http://edition.cnn.com/2005/WORLD/meast/07/23/egypt.explosions L (Letöltve: 2021.11.07.)

CONSTITUTIONAL History OF EGYPT. Letöltés helye: https://constitutionnet.org/country/egypt (Letöltve: 2021.11.07.)

CSICSMANN LÁSZLÓ (2010): Egyiptom: A Mubarak-rezsim liberalizációja és deliberalizációja, in. Csicsmann László (szerk.): Iszlám és modernizáció a Közel-Keleten. Az államiság eltérő modelljei., Budapest, Grotius Könyvtár

EGYPT ATTACK: GUNMEN KILL 235 IN SiNAI MOSQUE (2017), BBC. Letöltés helye: $\quad$ https://www.bbc.com/news/world-middle-east-42110223 (Letöltve: 2021.11.07.)

EGYPT BOMB KILLS 21 AT ALEXANDRIA COPTIC CHURCH (2011) . Letöltés helye: $\quad$ https://www.bbc.com/news/world-middle-east-12101748 (Letöltve: 2021.11.07.)

EGYPT BOMB KILLS NEW YEAR CHURCHGOERS (2011), The Guardian. Letöltés helye: https://www.theguardian.com/world/2011/jan/01/egypt-bomb-killsnew-year-churchgoers (Letöltve: 2021.11.07.)

Egypt EXECutes Islamic EXTREMist Hesham Ashmawy (2020), The Arab Weekly. Letöltés helye: https://thearabweekly.com/egyptexecutes-islamic-extremist-hesham-ashmawy (Letöltve: 2021.11.07.) 
Öngyilkos merényletek Egyiptomban a 2004 és 2020 közötti időszakban - Az öngyilkos merényletek elkövetési módjainak vizsgálata szervezettség alapján, a vallás szerepének

figyelembevételével

EGYPT EXPLOSION: TOURISTS ON BUS INJURED NEAR GIZA PYRAMIDS (2019), BBC. Letöltés helye: https://www.bbc.com/news/world-middleeast-48328793 (Letöltve: 2021.11.07.)

EGYPT: SHIFTING TACTICS BY ARMED GROUPS CURB SINAI DEVELOPMENT (2020), Al- Jazeera. Letöltés helye: https://www.aljazeera.com/news/2020/11/9/egypt-shifting-tactics-byarmed-groups-curb-sinai-development (Letöltve: 2021.11.07.)

EGYPT: SUICIDE BLAST IN CAIRO TOURIST AREA KILLS THREE POLICEMEN (2019), Al Jaazera. Letöltés helye: https://www.aljazeera.com/news/2019/2/19/egypt-suicide-blast-incairo-tourist-area-kills-three-policemen (Letöltve: 2021.11.07.)

EGYPTIAN OFFICIALS: ROADSIDE BOMBING IN SINAI KILLS 2 POLICE (2021), Arab News. Letöltés helye: https://apnews.com/article/police-egyptmiddle-east-islamic-state-group-bombings94f6eadebb7c9ecd430f652192fd2ca1 (Letöltve: 2021.11.07.)

EGYPT'S COPTIC CHURCHES HIT BY DEADLY BLASTS ON PALM SUNDAY (2017), BBC. Letöltés helye: https://www.bbc.com/news/world-middleeast-39544451 (Letöltve: 2021.11.07.)

FAHIM, KAREEM (2011): Fatal Bomb Hits a Church in Egypt, New York Times. Letöltés helye: https://www.nytimes.com/2011/01/02/world/middleeast/02egypt.htm $\underline{1}$ (Letöltve: 2021.10.28.)

FARID, SOFIA (2018): Deadly conflict brews within Coptic Church in Egypt's Wadi al-Natroun, Alarabiya News. Letöltés helye: https://english.alarabiya.net/features/2018/08/12/ANALYSIS-Deadlyconflict-brews-within-Coptic-Church-in-Egypt-s-Wadi-al-Natroun(Letöltve: 2021.11.07.)

FISHER, MAX (2013): Why Egypt's crackdown on the Muslim Brotherhood is bad for everyone, Washington Post. Letöltés helye: https://www.washingtonpost.com/news/worldviews/wp/2013/07/10/ why-egypts-crackdown-on-the-muslim-brotherhood-is-bad-foreveryone/ (Letöltve: 2021.11.07.)

GAZDIK GYULA (2017): Fejezetek Egyiptom modern kori történetéből (1805-2013), Budapest, Dialóg Campus Kiadó

GLOBAL TERRORRIST DATABASE. Letöltés helye: https://www.start.umd.edu/gtd/search/Results.aspx?search=Egypt\&sa.

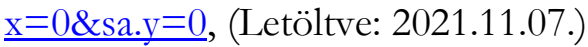


Halawi, Jailan (2011): Clamp-down in Sinai, Al-Ahram. Letöltés helye: https://web.archive.org/web/20110819022837/ (Letöltve: 2021.11.07.)

HANNA, MiCHAEL WAHID (2019): Excluded and Unequal, Copts on the Margins of the Egyptian Security State, The Century Foundation. Letöltés helye: https://tcf.org/content/report/christian-exclusion-fromegypts-security-state/?agreed=1 (Letöltve: 2021.11.07.)

Hassan, Ahmed Mohamed et AL. (2017): Islamic State seeks to impose religious rules in Egypt's North Sinai, Reuters. Letöltés helye: https://www.reuters.com/investigates/special-report/egypt-politicssinai/ (Letöltve: 2021.11.07.)

HendawI, Hamza (2017): Suicide bombers kill 44 at Palm Sunday services in Egypt, AP News. Letöltés helye: https://apnews.com/article/88b8fef3a96e433c902a303cd5db928e (Letöltve: 2021.11.07.)

Human Rights WATCh Report (2005.): Mass Arrest and Torture in Sinai, Letöltés helye: https://www.hrw.org/reports/2005/egypt0205/3.htm (Letöltve: 2021.10.09.)

IDRIS, IFFAT (2017.): Sinai Conflict Analysis, University of Birmingham, Birmingham

Islamic StATE: Egyptian Militants PLEDGE LOYALTY (2013), BBC, Letöltés helye: https://www.bbc.com/news/world-middle-east29993183 (Letöltve: 2021.10.09.)

IssaCHAROFF, Avi (2011): Report: Three Egyptians Took Part in Terrorist Attacks on Southern Israel, Haaretz. Letöltés helye: https://www.haaretz.com/1.5154682 (Letöltve: 2021.11.07.)

KATZ, YAAKOV (2011): Egypt launches massive operation to control Sinai, Jerusalem Post. Letöltés helye: https://www.jpost.com/defense/egyptlaunches-massive-operation-to-control-sinai (Letöltve: 2021.11.07.)

Khalifa, Mona ET AL. (2000): Population Growth in Egypt, A Continuing Policy Challenge, Rand Corporation. Letöltés helye: https://www.rand.org/pubs/issue papers/IP183.html (Letöltve: 2021.11.07.)

KIENLE, EBERHARD (1998): More than a response to Islmaism: The political deliberalizaton of Egypt in the 1990's, The Middle East Journal, Vol. 52., No. 2., tavaszi szám

KIFner, JOHn (1986): Egypt's Army Praised In Quelling Riots, But For Mubarak, Crisis Is Not Over, New York Times. Letöltés helye: https://www.nytimes.com/1986/03/09/world/egypt-s-army-praised-in- 
Öngyilkos merényletek Egyiptomban a 2004 és 2020 közötti időszakban - Az öngyilkos merényletek elkövetési módjainak vizsgálata szervezettség alapján, a vallás szerepének

figyelembevételével

quelling-riots-but-for-mubarak-crisis-is-not-over.html

(Letöltve:

2021.03.28.)

KIRKPATRICK, DAVID (2019): Is the Muslim Brotherhood a Terrorist Group?, New York Times Letöltés helye: https://www.nytimes.com/2019/04/30/world/middleeast/is-themuslim-brotherhood-terrorist.html (Letöltve: 2021.10.09.)

MACFARQuHar, NeIL (2005): Bombing at Cairo Tourist Site Leaves 2 Dead, 18 Wounded, New York Times, Letöltés helye: https://www.nytimes.com/2005/04/08/world/africa/bombing-atcairo-tourist-site-leaves-2-dead-18-wounded.html (Letöltve: 2021.11.07.) MAJOROSI ÁdÁM (2020): Aszimmetrikus hadviselés Egyiptomban, Szakmai Szemle, 2020. évfolyam, 3.szám. Letöltés helye: https://www.knbsz.gov.hu/hu/letoltes/szsz/2020 3 szam.pdf (Letöltve: 2021.11.15.)

MAJOROSI ÁDÁM (2019): Terrorellenes műveletek a Sínai-félszigeten, Hadtudományi Szemle. 2019.évf., 4.szám. Letöltés helye: https:// folyoirat.ludovika.hu/index.php/hsz/article/view/256 (Letöltve: 2021.11.15.)

MALSIN, JARED (2015): Egypt says terror attack foiled at temple in tourist city of Luxor, The Guardian. Letöltés helye: https://www.theguardian.com/world/2015/jun/10/egyptian-touristcity-of-luxor-hit-by-suicide-bomb-attack (Letöltve: 2021.11.07.)

MANDOUR, MAged (2018): Egypt's Comprehensive Military Operation, 2018, Carnegie Endowment for International Peace. Letöltés helye: https://carnegieendowment.org/sada/75556 (Letöltve: 2021.11.07.)

MCMANUS, AllisON (2020.): The Egyptian Military's Terrorism Containment Campaign in North Sinai, Carnegie Endowment for International Peace. Letöltés helye: https://carnegieendowment.org/sada/82218 (Letöltve: 2021.11.07.)

Mohamad, Amer (2019.): Superficial Gains, but No Lasting Success in Sinai 2018 (2019.), The Tahrir Institute for Middle East Policy. Letöltés helye: https://timep.org/commentary/analysis/superficial-gains-but-nolasting-success-in-sinai-2018/ (Letöltve: 2021.11.07.)

MUSLIM BROTHERHOOD FORMED 13 TERRORIST GROUPS IN EGYPT: NGO (2020), Egypt Today. Letöltés helye: https://www.egypttoday.com/Article/1/81764/Muslim-Brotherhoodformed-13-terrorist-groups-in-Egypt-NGO (Letöltve: 2021.11.07.) 
Myre, Greg ET AL. (2005): Death Toll Rises to at Least 90 in Bombings at Egyptian Resort New York Times. Letöltés helye: https://www.nytimes.com/2005/07/24/world/middleeast/death-tollrises-to-at-least-90-in-bombings-at-egyptian.html (Letöltve: 2021.10.27.) Poland, JAMES M (2003): Suicide Bombers: A GLobal Problem. Humboldt Journal of Social Relations. Vol. 27. No.2. Letöltés helye: https://www.jstor.org/stable/23524155 (Letöltve: 2021.11.15.)

PRESIDENT SisI REVIEWS PROGRESS OF SINAI DEVELOPMENT PROJECTS (2020.), Egypt Independent. Letöltés helye: https://egyptindependent.com/president-sisi-reviews-progress-of-sinaidevelopment-projects/ (Letöltve: 2021.11.04.)

SCHWEITZER, YORAM (2016): The Weakening of Wilayat Sinai, The Institute for National Security Studies. Letöltés helye: https://www.inss.org.il/publication/the-weakening-of-wilayat-sinai/ (Letöltve: 2021.10.29.)

Sinai Province: Egypt's most DANgerous Group (2016), BBC Monitoring. Letöltés helye: https://www.bbc.com/news/world-middleeast-2588250 (Letöltve: 2021.10.28.)

SINAI SECURITY STYMIED BY CONTINUED TERRORIST ATTACKS (2015), AlMonitor. Letöltés helye: https://www.almonitor.com/originals/2015/04/egypt-wilayat-sinai-salafist-jihad-attackphotos.html . (Letöltve: 2021.03.28.)

TERror BOMbINGS Hit TABA AND RAS A-SATAN IN SINAI (2004), Foreign Ministry of Israel. Letöltés helye: https://mfa.gov.il/MFA/MFAArchive/2004/Pages/Sinai \%20terror\%20bombings $\% 207-O c t-2004$.aspx (Letöltés: 2021.10.09.)

THAROOR, IsHAAN (2015): How Yemen was once Egypt's Vietnam, Washington post. Letöltés helye: https://www.washingtonpost.com/news/worldviews/wp/2015/03/28/ how-yemen-was-once-egypts-vietnam/ (Letöltve: 2021.10.29.)

Thorsten, Hoffmann (2011): The Muslim Brotherhood in Egypt pursuing moderation within an authoritarian environment, Monterey, Naval postgraduate School

THREE DEAD AFTER CAIRO ATTACKS (2005), RTE. Letöltés helye: https://www.rte.ie/news/2005/0430/62594-egypt/ (Letöltve: 2021.03.27.)

UN REPORT (2013): Hunger, poverty rates in Egypt up sharply over past three years. Letöltés helye: 
Öngyilkos merényletek Egyiptomban a 2004 és 2020 közötti időszakban - Az öngyilkos merényletek elkövetési módjainak vizsgálata szervezettség alapján, a vallás szerepének figyelembevételével

https://news.un.org/en/story/2013/05/440182-hunger-poverty-ratesegypt-sharply-over-past-three-years-un-report\#.VwvN-qSLShc (Letöltve: 2021.11.07.)

US SANCTIONS EGYPT'S HASM, TARGETS ISIS-AFFILIATE (2021), The Arab Weekly. Letöltés helye: https://thearabweekly.com/us-sanctions-egyptshasm-targets-isis-affiliate (Letöltve: 2021.07.22.)

VAUSE, JOHN ET AL (2004): Death toll rises in Egypt tourist bombings, CNN. Letöltés helye:

https://edition.cnn.com/2004/WORLD/meast/10/09/egypt.explosion s/ (Letöltve: 2021.03.27.)

WALLIS, WILliAM (2005.): Deathtoll from Cairo bazaar bomb rises to three: Financial Times. Letöltés helye: https://www.ft.com/content/6b0561f6a7fa-11d9-87a9-00000e2511c8 (Letöltve: 2021.03.27.)

WiCKHAM, CARRIE RosefsKy (2003): The Muslim Brotherhood, Evolution of an Islamist Movement, Princeton, Princeton University Press

WorLdBANK REPORT (2006), UN, Arab Republic Of Egypt, Urban Sector Update,3-4.o. Letöltés helye: https://documents1.worldbank.org/curated/en/749891468023382999/ pdf/411780v10REVIS1Box0327393B01PUBLIC1.pdf

(Letöltve: 2021.07.20.)

ZAID, MOHAMMED ABU (2020): Egyptian minister discusses agreements to finance Sinai Development Program, Arab News. Letöltés helye: https://www.arabnews.com/node/1735636/middle-east $\quad$ (Letöltve: 2021.03.29.)

ZEGHAL, MALIKA (1999): Religion and Politics in Egypt: The Ulema of alAzhar, Radical Islam, and the State (1952-94), International Journal of Middle East Studies, Vol. 31., No. 3., augusztusi szám, Cambridge University Press

ZuHur, SHERIFA (2005): A New Phase for Jihad in Egypt? Terrorism Monitor, Vol. 3., No.10. Letöltés helye: https://jamestown.org/program/a-new-phase-for-jihad-in-egypt/ (Letöltve: 2021.07.30.) 